\title{
Variations of Thoracic Splanchnic Nerves and its Clinical Implications
}

\author{
Variaciones de los Nervios Esplácnicos Torácicos y sus Implicancias Clínicas \\ "Tony George Jacob; ** Surbhi Wadhwa; ***Shipra Paul \& ****Srijit Das
}

JACOB, G. T.; WADHWA, S.; PAUL, S. \& DAS, S. Variations of thoracic splanchnic nerves and its clinical implications. Int. J. Morphol., 23(3):247-251, 2005.

SUMMARY:The present study reports an anomalous branching pattern of the thoracic sympathetic chain. At the level of T3 ganglion, an anomalous branch i.e accessory sympathetic chain (ASC) descended anteromedial to the main sympathetic chain (MSC). The MSC and the ASC communicated with each other at the level of T9, T10 and T11 ganglion, indicating the absence of classical pattern of greater, lesser and least splanchnic nerves on the right side. However, on the left side, the sympathetic chain displayed normal branching pattern. We opine that the ASC may be representing a higher origin of greater splanchnic nerve at the level of T3 ganglion and the branches from MSC at T9, T10 and T11 ganglion may be the lesser and least splanchnic nerves, which further joined the ASC (i.e presumably the greater splanchnic nerve) to form a common trunk. This common trunk pierced the right crus of diaphragm to reach the right suprarenal plexus after giving few branches to the celiac plexus.

Awareness and knowledge of such anatomical variants of thoracic sympathetic chain may be helpful to surgeons in avoiding any incomplete denervation or preventing any inadvertent injury during thoracic sympathectomy.

KEY WORDS: Splanchnic nerves; Sympathetic chain; Trunk thoracic; Ganglion.

\section{INTRODUCTION}

The sympathetic chain are two ganglionated nerve cords lying on either side of the vertebral column, extending from the cranial base to the coccyx.

Each chain passes into the abdomen beneath the medial arcuate ligament to continue as the lumbar sympathetic chain.

The sympathetic innervation to head and neck is mainly from T1-3. The sympathetic nerves destined for the upper extremity is from T2-3 and those meant for the heart is from $\mathrm{T} 2-5$.

The sympathetic nerves for the abdomen and pelvis are called splanchnic nerves. The greater splanchnic nerve arises from T5-9 and terminates in the celiac plexus. The lesser splanchnic nerve originates from T10-11 and ends in the aortico-renal plexus, while the least splanchnic nerve comes from the T12 segment and synapses in the renal plexus. These nerves carry pre-ganglionic fibers, pierce the diaphragmatic crura and supply the viscera through the plexuses (Standring, 2005).

The present study reports an anomalous branching pattern of the right sympathetic chain i.e ASC originating at level of the T3 ganglion. We presume that this might be the anomalous higher origin of the greater splanchnic nerve, which ran parallel to the MSC on its anteromedial aspect. The lesser and least splanchnic nerves were found to be emerging from the MSC and communicating with the greater splanchnic nerve at the level of T9, T10 and T11, respectively. The ASC terminated in the suprarenal plexus with a few branches to the celiac plexus.

\footnotetext{
* Post Graduate Student, Department of Anatomy, Maulana Azad Medical College, New Delhi, India.

** Senior Resident, Department of Anatomy, Maulana Azad Medical College, New Delhi, India.

**** Director Professor, Department of Anatomy, Maulana Azad Medical College, New Delhi, India.

***** Associate Professor, Department of Anatomy, Maulana Azad Medical College, New Delhi, India.
} 
Although there are less reports on presence of accessory splanchnic nerves (Standring), the study of such variations supplemented with necessary histological picture have been rarely reported. The present study is a humble attempt to report such an anomaly with respect to topographical and microscopic anatomy.

The anomalous branching pattern of the right sympathetic chain as found in the present case, is a rare anomaly which may be of immense clinical importance. The awareness of such anatomical variants of sympathetic chain may be helpful for surgeons in planning sympathectomy at a desired level.

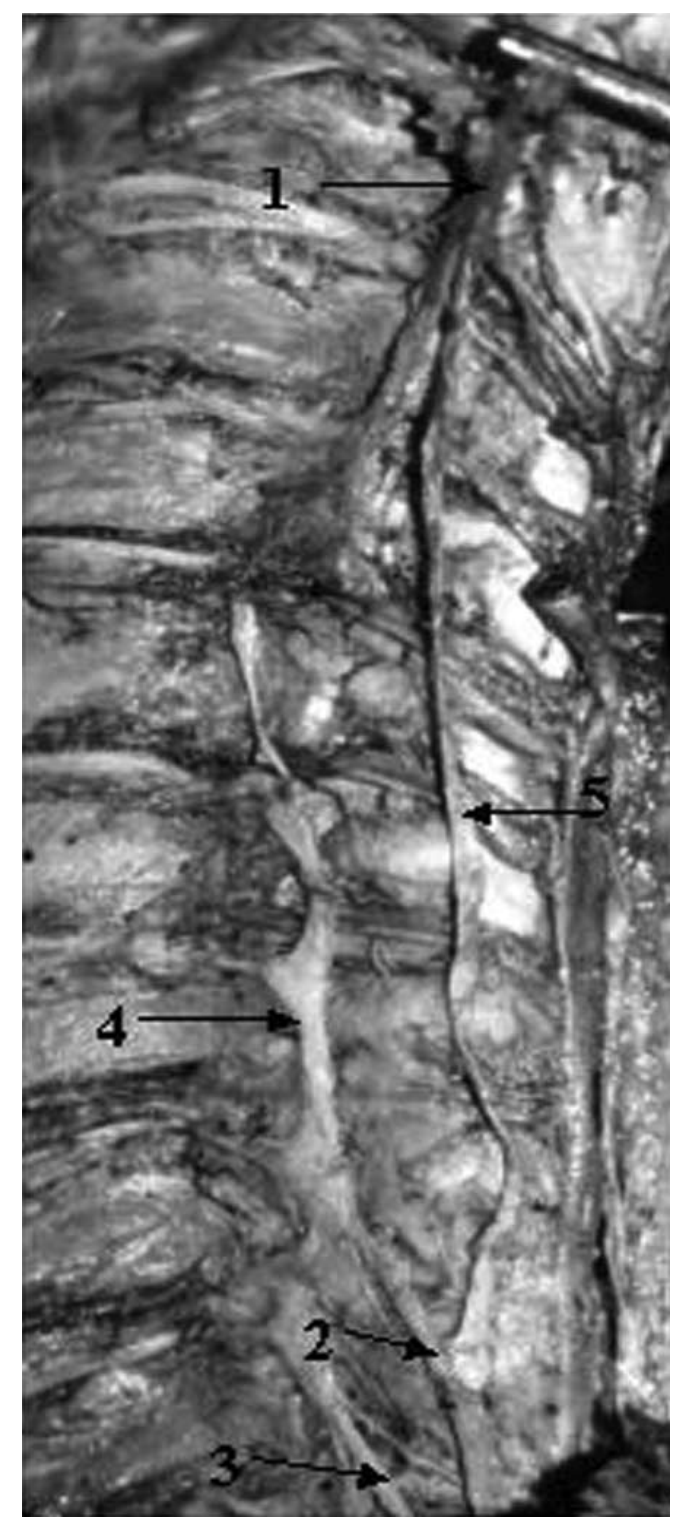

Fig. 1. Photograph showing the branching of the MSC (4) at the T3 gsnglion (1), the ASC (5) and the connections given off at T9 (2) and T10 (3).

\section{MATERIAL AND METHOD}

Over a period of 10 years, out of 90 cadavers dissected for posterior mediastinum, only a single cadaver showed the anomalous branching pattern of sympathetic chain. The anomalous sympathetic chain was displayed and photographed. A segment of the MSC and the ASC at the level of origin i.e T3 ganglion and a portion of the anomalous nerve with the ganglion were processed for microscopic study and stained with hematoxylin and eosin.

\section{RESULTS}

During dissection of 90 cadavers over a period of 10 years, we noticed a single case of ASC in a single cadaver $(1.11 \%)$. The rarity of such anomaly can be spelt out from its incidence as seen in this case.

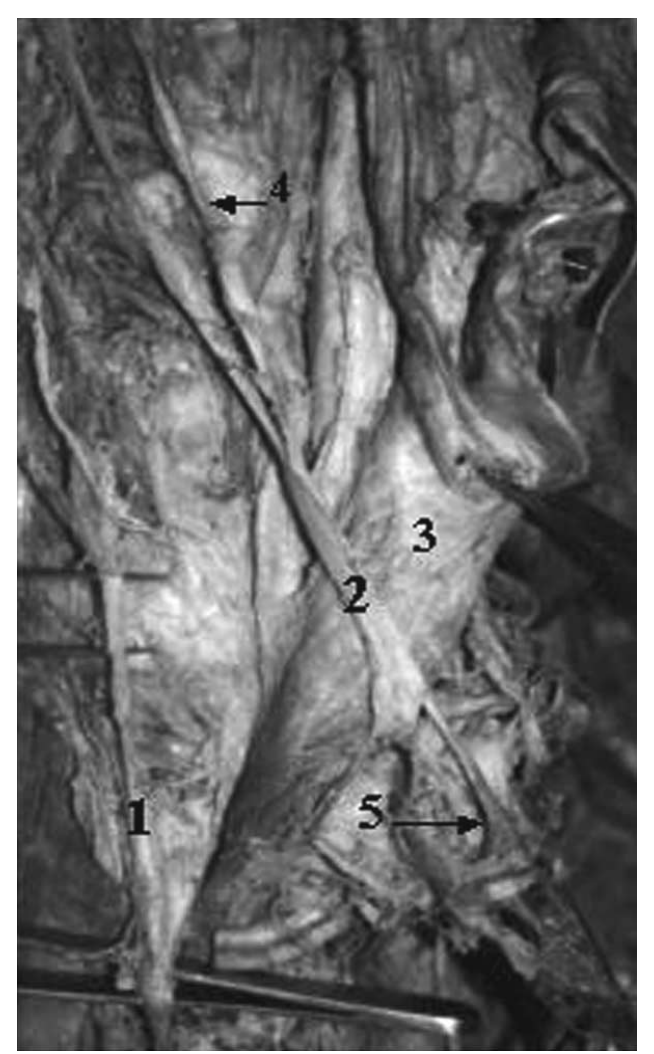

Fig. 2. Photograph showing the termination of the ASC (2) into the right suprarenal (5) after piercing the right crus of diaphragm (3) and getting the third connection (4) from the MSC (1) at T11. The MSC (1) continues as the lumbar sympathetic chain. 


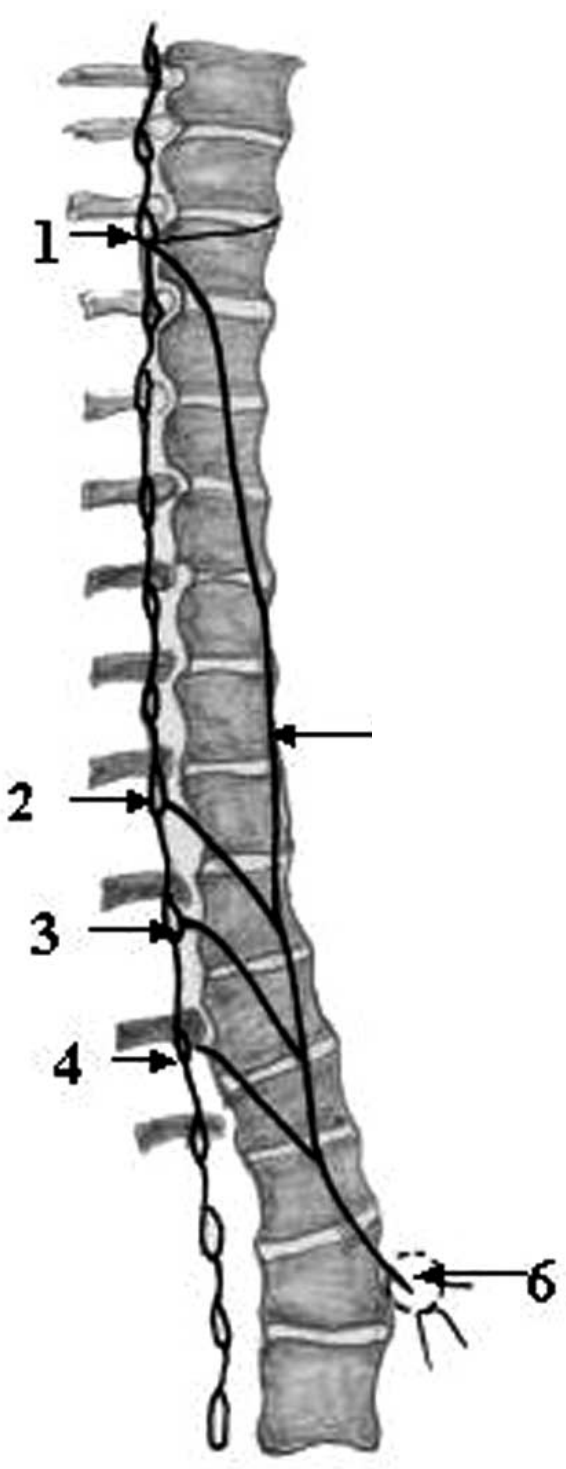

Fig. 3. Line diagram showing the right sympathetic chain trifurcating at $\mathrm{T} 3$ ganglion (1); connections between the MSC and ASC (5) at T9 (2), T10 (3), T11 (4) and the termination of the ASC in the right suprarenal plexus (6).

In this particular case, the right hemithorax showed a variation in the branching pattern of the sympathetic chain. The branches were traced from their origin to their termination. The branch originating at the level of T3 ganglion appeared to be beaded and descended parallel, anteromedial to the MSC and continued into the abdomen, through the right crus of diaphragm, where it terminated in the right suprarenal plexus, after giving few branches to the celiac plexus (Fig. 2). The MSC continued into the abdomen as the lumbar sympathetic trunk under the medial arcuate ligament.

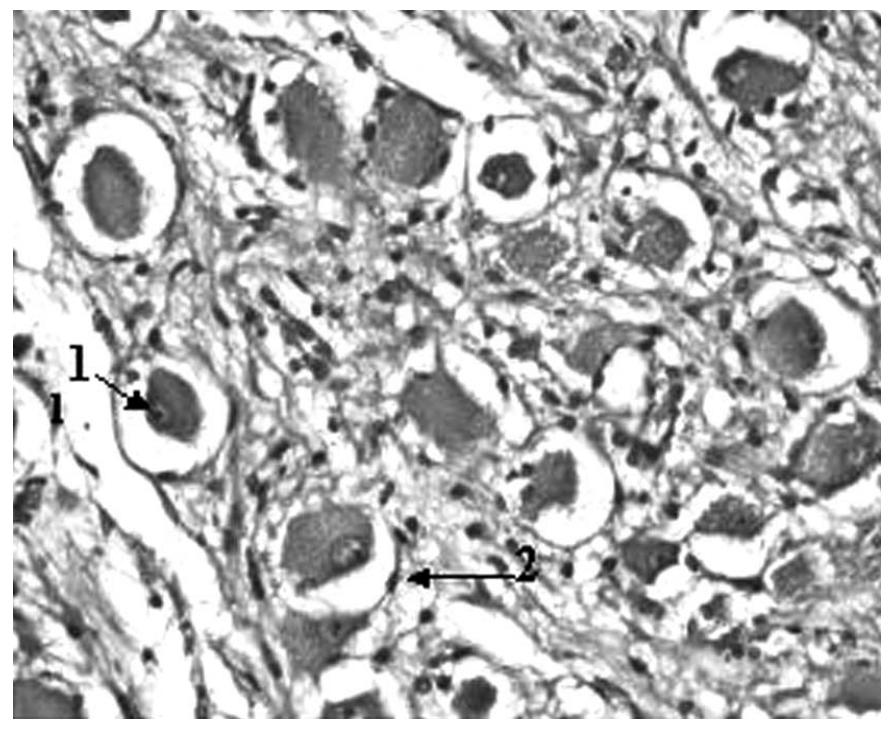

Fig. 4. Stained section of the beaded area on the anomalous splanchnic nerve showing a ganglion cell with cell with prominent nucleus and nucleolus (1), surrounded by satellite cells (2). H. E. 400X.

On the right side, there were 3 communications between the anomalous ASC and the MSC, one each at the level of the T9, T10 and the T11 sympathetic ganglia respectively (Figs. 1 and 3), thus showing absence of classical pattern of greater, lesser or least splanchnic nerves as documented in standard textbooks. On the left side, the sympathetic chain and its branches were normal with the greater, lesser and least splanchnic nerves originating from the level of T5-9, T 10-11 and T12. respectively.

Microscopic examination of the MSC and ASC showed typical features of autonomic ganglia (Fig.4). Most ganglion cells had eccentric nuclei with prominent nucleoli and were surrounded by 5-8 satellite cells.

\section{DISCUSSION}

The present study showed absence of separate greater, lesser and least splanchnic nerves in the right hemithorax. There was an anomalous nerve which originated at the level of the T3 ganglion and had communications with MSC at the level of T9, T10 and T11. We presume that this abnormal nerve was the greater splanchnic nerve and that the communication which were noticed at the level of T9, T10 and T11 were probably the lesser and least splanchnic nerves which joined the greater splanchnic nerve to form a common splanchnic nerve. A higher origin of the greater splanchnic nerve at the level of T4 has been reported (Kuntz, 1934 and Reed, 1951) but in the present study, we report the same at a 
higher level i.e T3 . To the best of our knowledge, only a single study in the past has reported a higher origin of greater splanchnic nerve at T3 level, but it was not supplemented with necessary histological study (Naidoo et al., 2001). There are past reports of a common trunk for the greater and lesser splanchnic nerves (Naidoo et al.) but our study showed a common trunk of greater, lesser and least splanchnic nerves after each of them had originated separately from MSC. There were no visible communications from ganglia T4 -8 , therefore we presume that the segmental branching of the splanchnic nerves, which should have contributed to the formation of the greater splanchnic nerve from T 5- 9 must have been altered. ASC was found to be ganglionated throughout its course, the evidence of which was proved histologically (Fig.4). Similar reports of ganglionated splanchnic nerves have also been documented earlier (Hoffmann, 1957).

Osteophytic degenerations of the vertebral column are more common on the right than the left side of the body as reported by Lipschitz et al. (1988). The study also highlighted the role of osteophytes comprising the prevertebral branches of the sympathetic system thereby causing chronic pain. Many elderly patients suffer from syndromes of the sympathetic pathways which may be due to osteophytic changes compressing the sympathetic nerves and its branches (Lipschitz et al.). By virtue of its location anteromedial to the MSC, the ASC is more likely to be affected by osteophytic degenerative changes of the vertebral column in the thorax.

The sympathetic nerve supply for the upper limb, head and neck and thoracic viscera arise from the spinal segments T3-6, T1-2 and T2-5, respectively (Standring). Vasomotor tone modified by the sympathetic output is responsible for diseases like essential hypertension, thromboangitis obliterans, Raynauds phenomenon, angina pectoris (Hoffmann) and is one of the few causes of 'Carpal Tunnel' and 'Thoracic Outlet Syndrome'. Referred pain from abdominal or thoracic viscera are also carried by these nerves (Lipschitz et al.). In the present study, the greater splanchnic nerve appeared to arise from the T3 ganglion and since T3 is involved in the sympathetic nerve supply of upper limb, head and neck and heart, the clinical implications of such an anomaly can be widespread.

Pain arising from the vertebral column is also carried by sympathetic nerves (Groen et al., 1990). Symptoms may occur either due to stimulation or inhibition of the nerves. The sympathetic trunk and splanchnic nerves are commonly affected by anterior osteophytes of the vertebral column (Nathan, 1987). Thoracic surgeons using VATS (Video Assisted Thoracoscopic Surgery) in the posterior mediastinum should be particularly careful in noting anomalous formations of the sympathetic system to prevent fibrotic changes in the pathways (Zelle et al., 2002) that leads to chronic back pain and visceral symptoms like painful spasms (Lipschitz et al.).

The classical teaching of splanchnic neurectomy is to resect the sympathetic chain at T5 ganglion. This operation is used in the treatment of the nagging pain in chronic pancreatitis and pancreatic cancer (Naidoo et al.). The success of the sympathetic denervation procedure depends upon the presence or absence of visible or barely perceptible accessory ganglia and pathways other than those classically described (Naidoo et al.; Hoffmann; Kuntz \& Alexander, 1950; Ehrlich $\&$ Alexander, 1951). The region of second thoracic ganglion is considered as a key ganglion for any sympathectomy (Ramsaroop et al., 2004). Considering the close proximity of the aberration reported in the present study, it would be of great significance to the thoracic surgeons attempting splanchnic neurectomy to prevent any inadvertent injury to the surrounding structures.

JACOB, G. T.; WADHWA, S.; PAUL, S. \& DAS, S. Variaciones de los nervios esplácnicos torácicos y sus implicancias clínicas. Int. J. Morphol., 23(3):247-251, 2005.

RESUMEN: El presente estudio relata un patrón de ramos anómalos de la cadena simpática torácica. A nivel del ganglio de T3, un ramo anómalo denominado cadena simpática accesoria (CSA), descendió anteroedialmente a la cadena simpática principal (CSP). La CSP y la CSA comunicadas cada una con la otra a nivel de los ganglios de T9, T10 y T11, indicaban la ausencia de patrones clásicos de nervios esplácnicos mayor, menor y mínimo del lado derecho. Sin embargo, en el lado izquierdo, la cadena simpática estaba dispuesta en un de patrón normal. Nuestra opinión es que la CSA estaría representando un origen alto del nervio esplácnico mayor a nivel del ganglio de T3 y que los ramos de CSP de los ganglios T9, T10 y T11 podrían ser los nervios esplácnicos menor y mínimo, los cuales se unían lejos a la CSA (presumiblemente el nervio esplácnico mayor) para formar un tronco común. Este tronco común perforaba la cruz derecha del diafragma para alcanzar el plexo suprarrenal derecho, dando después pequeños ramos para el plexo celiaco.

El conocimiento de tales variaciones de la cadena simpática torácica pueden ser de ayuda para los cirujanos, pudiendo ser evitada alguna denervación incompleta o prevenir algún daño involuntario durante la simpactectomía torácica.

PALABRAS CLAVE: Nervios esplácnicos; Cadena simpática; Tronco simpático; Ganglio. 


\section{REFERENCES}

Ehrlich, Jr. E. \& Alexander, W. F. Surgical implications of upper thoracic independent sympathetic pathways. Arch. Surg., 62(5):609-14, 1951.

Groen, G. J.; Baljet, B.; Drukker, J. Nerves and Nerve Plexuses of the Human Vertebral Column. Am. J. Anat., 188 (3):282-96, 1990.

Hoffman, H. H. An Analysis of the Sympathetic Trunk and Rami in the Cervical and Upper Thoracic Regions in Man. Ann. Surg., 145(1):94-103, 1957.

Kuntz, A. The Anatomie Nervous System. 2. ed. Baillière, Tindall and Cox, London, 1934. pp. 28-57.

Kuntz, A. \& Alexander, W. F. Surgical implications of lower thoracic and lumbarindependent sympathetic pathways. Arch. Surg., 61(1):1007-18, 1950.

Lipschitz, M.; Lipschitz, L. B \& Nathan, H. Thoracic Sympathetic Trunk Compressions by Osteophytes Associated with Arthritis of Costovertebral Joint. Anatomical and Clinical Considerations. Acta. Anat., 132(1):48-54, 1988 .

Correspondence to:

Received: 07-06-2005

Prof. Shipra Paul. $\mathcal{M B B S}, \mathcal{M D}$.

$\mathcal{D}-I I / \mathcal{A}-75$,

Nanakpura, Moti Bagh - South

New Delfi-110021

$I \mathcal{N} \mathcal{D} I \mathcal{A}$

Tel: 91-11-26119751

E-mail: drshipra14@yahoo.com
Naidoo, N.; Partab, P.; Pather, N.; Moodley, J; Singh, B. \& Satyapal, K. S. Thoracic splanchnic nerves: Implications for splanchnic denervation. J. Anat., 199(Pt 5):585-90, 2001.

Nathan, H. Osteophytes of the Spine Compressing the Sympathetic Trunk and Splanchnic Nerves in the Thorax. Spine, 12(6):27-32, 1987.

Ramsaroop, L; Singh, B; Moodley, J; Partab, P \& Satyapal K.S. Anatomical Basis for a Successful Upper Limb Symapthectomy in the Thoracoscopic Era. Clinical Anatomy, 17:294-9, 2004.

Reed, A. F. The origins of the splanchnic nerves. Anat. Rec., 109(1):341, 1951.

Standring Susan. Gray's Anatomy. 39th edn, Elsevier Churchill Livingstone, New York, 2005. pp- 991.

Zelle, B.; Zeichen, J.; Pape, H. C; Weissenborn, K. \& Krettek, C. Upper sympathetic trunk lesion after video-assisted fracture stabilization of the thoracic spine: a case report. J. Spinal. Disord.Tech., 15(6):502-6, 2002. 
